\title{
THE UNIVERSITY OF NORTH CAROLINA INTERGENERATIONAL LEGAL ETHICS PROJECT: EXPANDING THE CONTEXTS FOR TEACHING PROFESSIONAL ETHICS AND VALUES
}

\author{
WALTER H. BENNETT, JR.*
}

I think the ethical tone of the Bar has dropped way below what's acceptable. I've never heard of such things. ... [A] former president of our local Bar ... [went] to prison for embezzlement. We've had lawyers disbarred for all sorts of things-and lawyers who were supposedly prominent members of the profession. The Bar's response is to say, "You take three hours every year in ethics." One of our judges had a little unfavorable publicity, and I wrote [the] Chief Justice ... and said, "I recommend that at the next judges' conference they have as their CLE the book, Everything I Need to Know I Learned in Kindergarten, because that's the basis of ethics.". . . If a lawyer doesn't know an ethical problem when it confronts him, that's the problem. They don't know whether they've got an ethical problem. They just barge ahead. And if you haven't got that gut feeling, "wait a minute here, there's something here," and look into it, they can give you all the courses in the world. It's not going to give you that.'

\section{INTRODUCTION: LEGAL ETHICS ON THE GUT LEVEL}

The University of North Carolina Law School Intergenerational Legal Ethics Project (the "UNC Project") is an effort to identify new course concepts and structures and other curricular innovations that can bring education in professional values to a deeper, more personal level. ${ }^{2}$ It attempts to forge a connection between the widely celebrated cerebral faculties of lawyers and law

\section{Copyright $\odot 1996$ by Law and Contemporary Problems}

* Clinical Professor of Law, University of North Carolina at Chapel Hill.

I wish to thank my colleagues Lissa L. Broome, Patricia L. Bryan, Ruth Ann McKinney, and Dean Judith W. Wegner at the University of North Carolina Law School, and Professor Thomas B. Metzloff of Duke University Law School for their advice and editorial suggestions.

1. Interview with Judge Frank W. Snepp, Mecklenberg County Superior Court, in Charlotte, N.C. (Feb. 25, 1993) (by UNC law student Kevin B. Bunn) (referring to ROBERT FulghUM, ALL I REALLY NEED TO KNOW I LEARNED IN KINDERGARTEN (1986)). All interviews were conducted as part of the oral history portion of the UNC Intergenerational Legal Ethics Project. All tapes and transcripts from interviews by the UNC Law School Oral History Project are deposited in the Southern Historical Collection in the William Round Wilson Library at UNC, Chapel Hill. Transcripts are available through the Kathrine R. Everett Law Library at the UNC Law School.

2. The Project is jointly funded by the UNC Law School and a grant from the W.M. Keck Foundation. The author is Program Director for the UNC Project, and Dean Judith W. Wegner of the UNC Law School is Senior Adviser. The Project is advised by a national committee composed of lawyers, law professors, oral historians, and teachers from other disciplines such as medicine, sociology, religion, and communication. 
students and their often hidden and unheeded hearts and souls. This is relatively new work for legal educators. ${ }^{3}$ At the outset, it has involved a redefinition of the appropriate parameters of ethical discourse.

Toward that end, the UNC Project has challenged certain traditional categories and assumptions. Among those are the false distinction between professional and personal ethics, the traditional barrier between the academy and the bar in their roles as teachers and arbiters of professional ethics, and the assumption that lectures and socratic dialogue are always the most appropriate pedagogical tools for law school. The UNC Project has tried approaches that permit ethical issues to be treated in the broader and deeper contexts of personal character development. Frequently, these approaches have relied on one form or another of narrative technique, usually in the form of collecting, reading, telling, or listening to lesson-teaching stories. But more central to the UNC Project is the premise that ethical learning is deep, internal learning-learning of the heart as well as the mind-and that this type of learning occurs best in a setting that is intimate, safe, and authentic for both teacher and student.

The UNC Project has attempted to create this setting by finding ways to promote teaching relationships between individuals and within small groups, both among law students and members of the bar. Such a setting allows a true, comprehensive reflection to take place on the profession and its values and on the values of the individuals engaged in the reflective process. ${ }^{4}$ Perhaps the most effective method the UNC Project has developed for creating this setting is a seminar based upon oral history interviews of lawyers and judges. This method requires law students to visit the offices and homes of members of the profession, record their life stories, and present those stories and their own reflections to the class. The UNC Project has also developed a three-hour ethics class that includes a one-hour mentoring program structured to bring lawyers and students together in reflective conversation. In the classroom

3. There have been numerous able and inspirational pioneers in the overall movement to bring the teaching of legal ethics to a more personal level. Among the legal scholars on whom I have relied the most are James R. Elkins at West Virginia University College of Law, David J. Luban at University of Maryland School of Law, and Thomas L. Shaffer at Notre Dame Law School. All have written extensively in criticism of traditional methods of teaching legal ethics and in suggesting new approaches. Perhaps the leading early article in this area is Roger C. Cramton, The Ordinary Religion of the Law School Classroom, 29 J. LEGAL EDUC. 247 (1978). I have also relied extensively on feminist critics of the legal profession and legal education and commentators on gender differences in psychological development and perception. Some of these critics include Carol Gilligan of the Harvard Graduate School of Education, Carrie Menkel-Meadow at the University of California at Los Angeles School of Law, Deborah L. Rhode at Stanford Law School, and Robin West at University of Maryland School of Law.

4. The reflective process, as it applies in an educational context, includes two aspects that are central to the work of the UNC Project: (1) setting learning in an experiential context, which engages the student in problems that are alive and real or, in some other way, mires the learning process in the fabric of real life experience and (2) building into the learning process a structure and encouragement for systematic reflection on what is being learned and the act of learning itself. The leading pioneer in the field of reflective learning is Donald A. Schön, who has written two seminal books in this area: The Reflective PRACTITIONER (1983) and EduCATING THE Reflective PRACTITIONER (1987). 
component of this course and in the oral history seminar, the UNC Project has experimented with various classroom teaching materials and techniques to engender reflective practices among students on issues of professional and personal ethics.

This article will describe in some detail the new techniques the UNC Project has developed and others it has tried to adapt to this new curriculum. Part II discusses three limitations of traditional legal pedagogy for teaching ethics and describes how the UNC Project has addressed them. Part III lays out the methodology of oral history and describes the mechanics of the legal ethics course. It also presents three elements that contributed to the success of the classroom component of the UNC Project.

\section{II}

\section{Limitations of Traditional APPROACHES to TEACHING LEgAL ETHICS}

The UNC Project has identified several assumptions underlying traditional approaches to teaching legal ethics that hamper the creation of effective contexts in which to address ethical reforms.

A. Traditional Approaches to Teaching Legal Ethics are Hampered by a Limited View of What Ethical Decisions Involve and How They Arise.

The ethical decisions lawyers and judges make involve much more than deciding whether and how to apply the appropriate rules of professional conduct. They involve much more than traditional notions of professional courtesy. Ethical decisions for lawyers and judges, as for all of us, involve personal, moral choices. They define who we are as people and who we want to be. They are inherently bound up in the contexts of our lives and call into play not only what we learn in law school, but all the parts of us that we have developed since birth and all the hopes we have for the future. The job of teaching professional ethics, then, is not so much "teaching" as it is finding ways to encourage individuals to look at their own lives in context and to learn to ask their own moral questions. The job of developing ethical lawyers is really the job of finding ways to help lawyers and law students develop as moral people.

\section{B. Traditional Approaches to Teaching Legal Ethics are Hampered by a Limited View of Who Lawyers Are.}

Lawyers are not just highly trained and skilled advocates, well paid professionals, political insiders, business associates, or very busy individuals who happen to have "other" (private) lives. They are people with lives in the broadest sense. They have childhoods, parents, grandparents, grammar school and high school experiences, first loves, college experiences, military service, prior careers, law school experiences, spouses, children, hobbies, futures, hopes, dreams, doubts, failures, and accomplishments. In short, lawyers are people and, like all people, they have unfolding life stories in which an infinite number 
of people, places, and events have influenced who they are and what values they cherish and bring to their work. Only in this broader context can truly meaningful discussions of the ethical issues relating to lawyers' lives and work occur. Without that context, we are left with limited hypotheticals structured for a syllogistic application of legal principles or professional rules. Under this incomplete model, ethical issues are artificially restricted and defined, debate is rule-oriented, and answers are likewise artificial and gravitate toward a bottom line. The image of the lawyer that emerges from such exercises is that of a disembodied professional whose only real concern in life is to practice professional skills within the broad boundaries of professional rules. It is an image that speaks to the mind, but not the heart.

\section{Traditional Approaches to Teaching Legal Ethics are Hampered by a Limited View of What Constitutes Effective Legal Education.}

The Holmesian admonition to teachers and learners of the law to "dispel a confusion between morality and the law [in order for] ... a right study and mastery of the law as a business with well understood limits"s serves well its stated purpose. But it is overly confining as a prescript for training professionals to make heavily weighted moral decisions in an increasingly complex society. Further, the success with which the Holmesian admonition has been applied in training persons to become highly skilled as abstract thinkers and legal analysts has itself worked to create a vacuum in the moral development of law students as well as practicing lawyers. ${ }^{6}$ Underlying most decisions about legal ethical education are assumptions that law schools and bar-sponsored CLE programs are not in the business of teaching moral values beyond a reasoned application of the appropriate rules of professional conduct and that law professors and members of the bar are not competent to engage students or fellow lawyers in discussions of moral values.

The UNC Project seeks to deal specifically with the vacuum created by the traditional model, and does so by unabashedly engaging lawyers, students, and professors in value-oriented discussions that range from the most professional to the most personal level. It assumes that competence to engage in this type of discussion comes not so much from training to think like a lawyer, but from life experience and the innate capacity (and inclination, if encouraged) in each of us to ask basic questions about life's purpose and meaning. The key to this type of learning is not so much who is teaching and who is learning and what their credentials are, but the setting in which it occurs. The UNC Project

5. Oliver Wendell Holmes, The Path of the Law, 10 HARV. L. REV. 457, 459 (1897).

6. See, e.g., Elliott M. Abramson, Puncturing the Myth of the Moral Intractability of Law Students: The Suggestiveness of the Work of Psychologist Lawrence Kohlberg for Ethical Training in Legal Education, 7 NOTRE DAME J. L. ETHICS \& PUB. POL'Y 223 (1993); Lawrence J. Landwehr, Lawyers as Social Progressives or Reactionaries: The Law and Order Cognitive Orientation of Lawyers, 7 L. \& PSYCHOL. REV. 39 (1982); Kurt M. Saunders \& Linda Levine, Learning to Think Like a Lawyer, 29 U.S.F. L. REV. 121 (1994). 
postulates that, given a setting that permits self-examination and self-revelation and active listening, serious people who are concerned about their moral development and the development of their profession will assist each other in reflection upon issues of life's purpose. They will engage in a process that occurs informally in every law office and courthouse in the country, where lawyers teach one another about lawyering and help one another with issues of professional and personal values. But they will do so within the UNC Project in a setting that is removed from the adversarial process and therefore safer for self-examination.

In terms of methodology, then, the UNC Project seeks ways to promote this type of learning. The UNC Project staff has done this by learning about educational theory, by conceptualizing ways in which promising aspects of that theory can be applied in the law school curriculum, and by developing techniques and experimenting with those techniques both in and out of the classroom. The following is a discussion of the more successful methods the UNC Project has utilized to date.

III

\section{Methodology: Using Oral History to Teach Professional and Personal Values}

The UNC Project has found that techniques used by oral historians are excellent tools for creating meaningful contexts for addressing ethical issues and has developed a seminar in which those techniques are combined with reflective practice and story telling in order to foster a deeper learning.

\section{A. The Oral History Interview as a Setting for Deep Learning}

Oral historians see two basic approaches to oral history': one focuses on the life of an individual person (frequently called "life histories" or "biographical histories"), ${ }^{8}$ and the other is a broader, more project-based approach where a number of interviews are used to cover a larger subject (frequently called "topical histories"). ${ }^{9}$ While both approaches have utility in the study of history

7. Paul Thompson, The Voice of the Past: Oral History 22-55 (2d ed. 1988); Valerie $R$. Yow, ReCORding ORal History: A PRACTICAL GUIDE FOR SOCIAL SCIENTISTS 143-44 (1994). For an excellent source on the forms and uses of oral history, including the oral history of lawyer's work and trials, see generally, Alessandro Portelli, ThE DEATH OF Luigi Trastuli and OTHER STORIES: FORM AND MEANING IN ORAL HISTORY (1991).

8. See generally, Yow, supra note 7, at 167-91.

9. A popular example of a work based on the biographical approach is THEODORE ROSENGARTEN, ALl GOD'S DANGERS: THE LIFE OF NATE SHAw (1974), which is based largely upon the oral history of an Alabama sharecropper during the mid-twentieth century. One of the most often cited examples of topical oral history is STUDS TERKEL, HARD TIMES: AN ORAL HISTORY OF THE GREAT DEPRESSION (1970). Of course, life stories of individuals frequently provide the basis for a broader, sociological/historical study. A recent, highly successful example of this is the use of life stories of textile workers to portray the history and culture of southern textile mills in JACQUELYN D. HALL ET AL., Like A Family: The MAKING OF A SOUTHERn CotTon Mill World (1987). 
and in legal education, ${ }^{10}$ the UNC Project uses the former approach in an oral history seminar to achieve a central pedagogical purpose: bringing law students into intimate contact with the life and personality of another person who has chosen and lived (or is living) a life in the law. Like mainstream oral historians, students in the oral history seminar record historical facts and information in the voice of the person interviewed. However, the ultimate goal of the UNC Project reaches beyond the traditional goals of oral historians to preserve the historical record. In the seminar, teachers seek to foster an intimate conversation between a student and an experienced lawyer. The student is there to learn about her own life as well as that of the person she is interviewing; the lawyer, by telling her life story, teaches both the student and herself through the process of self-reflection and revelation.

A typical interview may proceed something like this: The student is seated alone with the lawyer in the lawyer's law office or perhaps in her study or den at home. The student has researched the lawyer's life and has sufficient knowledge of key events in the lawyer's life to recognize possible areas of fruitful inquiry. This research might involve reading cases in which the interviewee participated as a lawyer or judge, researching old newspaper files from the subject's home town, interviewing law partners and acquaintances, or examining state archives and clippings on file in college and law school alumni offices. The purpose of the student's preliminary research is not to develop a thorough understanding of the life in question, but rather to help the student develop a guide to what directions the oral history interview might (and, in some cases, should) take.

The student and lawyer may have met and talked briefly before, or they may pass a few moments before the interview in light conversation, getting to know each other and discussing their expectations for the interview. The student might be nervous about the interview, especially if the interviewee is a famous or powerful member of the profession. However, the student's job is to put her subject at ease about the process and to reassure the subject about the purpose of the interview.

When the student and lawyer are ready, the interview begins. After a few preliminary questions concerning place and date of birth and names of parents and siblings, the student will ask the following types of questions about the lawyer's parents, ancestors, or earliest memories of childhood: "What are the first memories you have of growing up in Smithfield, North Carolina?" "Tell me about your relationship with your mother." "You said that your parents were poor. How did that affect your childhood?" These are questions that invite the lawyer to reveal something about herself as a person, to talk about herself as a child and about the formative relations and events in her life. They serve to

10. It is easy to conceive, for example, how oral histories could be used to do a complete study of a noteworthy legal case or problem by interviewing all the participants (given, of course, limitations imposed by the attorney-client privilege and rules governing confidentiality). 
put the interview on a relatively intimate level from the outset and often elicit sincere and tender memories. One student elicited this representative example:

The only thing I can remember about Smithfield is that I was in a carriage, and my mother was crying. She was pushing the carriage, and my sister-I was the youngest of three children-she was ... sitting at the ... foot of the carriage. And my brother was holding on to the arm of the carriage. And mother was crying. I can remember this. I was a mere infant.

They always said I couldn't remember it until I had a case down there ... . I guess I was fifty years of age. And Daddy was riding with me, and I had a person drive me. We went down into town, and we . . turn[ed] left. I could see it all just as if it was just happening. After we got to a certain corner, I said, "Go across that track. That's the track where mother was pushing the baby carriage." ... And I said, "Two more blocks," and I said, "turn left there ... . Dad, that's the house where I was born right there." There was a horse grazing in the yard that day that we went there .... It wasn't too far from the courthouse .... .

And I know what happened now. They interpreted it for me as I grew older .... $[\mathrm{M}] \mathrm{y}$ father had purchased that house. He hadn't had the title searched. And it turned out to be somebody else's, and he couldn't pay them off, and we lost the house. And that's what she was crying about. ${ }^{11}$

\section{Another interview produced this memory:}

[M]y relation with my mother was extremely close . . , and I spent many, many hours at my mother's side, particularly as a youth, sharing ideas, discussing philosophical matters, right and wrong, relations between black and white, and those kinds of things that were really profound subjects for young people. I suppose that much of my education, so far as philosophical matters are concerned, probably came from my mother. ${ }^{12}$

Frequently, these earliest memories begin a discussion of personal values that carries through the entire interview and leads to a more philosophical discussion of professional values and the morality of lawyers' work later:

[E]ven though we grew up in poverty, we never felt poor ... . I didn't even know I was poor until I got grown because there was never ... any despair in the house; there was never a time when there was a lot of complaining in the house. It was always whatever we had was what we had and it was good even if it was just biscuits and syrup for dinner ... . [B] ut I was never told that we couldn't afford anything but biscuits and syrup and that's what you had to eat. I was always told how good the biscuits and syrup were-and they were good .... [Laughter] So we learned to make do with whatever we had, to enjoy each other, to learn to love each other, to support each other and help each other. I just learned the values there that I have carried through life. I give all the credit to my parents. They did what they could with what they had. ${ }^{13}$

Later, while discussing his work as a lawyer, this same interviewee responded to a question about the values that are important to him as a lawyer:

As trite as it may seem, I think one value is to understand the human worth of every individual. No matter what a person's circumstances, . . . they're entitled to the equal protection of the law. They're entitled to participate in the fruits of this society. I

11. Interview with Elreta N. Melton Alexander Ralston, Attorney, in Greensboro, N.C. (Feb. 18, 1993) (by UNC law student Anna B. Perez).

12. Interview with B.B. Olive, Attorney, in Durham, N.C. (Jan. 27, 1994) (by UNC law student Jennifer Marsico).

13. Interview with James E. Ferguson, Attorney, in Charlotte, N.C. (Mar. 3, 1992) (by UNC law student Rudolph Acree, Jr.). 
think that as long as there is a single person who is denied that opportunity, then there is a reason for us to practice civil rights law. I think honesty is important, and I think ... self-confidence is important. And I think a sense of sacrifice is important. If there is one thing that bothers me about today's world, it is that we have become a lot more materialistic than we once were. And I think that materialism gets us away from the true, core values that make us strong as a people, that make us strong as a country, that make us strong as lawyers committed to bringing about change. So I think a sense of doing what one really believes to be right, a sense of doing something to advance someone other than yourself, and a sense of being able to do without, and not be so concerned about that big house, or that big car, fine clothes, and things like that. But just to be concerned about helping other people, concerned about eradicating racism, inequality, injustice. I think if one does that, the other fruits come. ${ }^{14}$

As a law professor and teacher of professional responsibility classes for more than five years, I am certain that if I stood before a class and delivered this same speech, it would meet an impregnable wall of indifference, skepticism, cynicism, and even outright rejection. The oral history interview, however, is a different setting from the typical law school classroom. Students' perceptions also differ when a noted trial lawyer, ${ }^{15}$ who is successful and admired in the profession, speaks from the heart to a student one-on-one. Then, when the student brings the lawyer's life story to the seminar and presents the messages from that story in her own words and in the recorded voice of the lawyer, the "magical" atmosphere of the oral history interview is, to some degree, recreated and, if done well, even enhanced. It becomes a place where a deeper level of communication can occur involving real listening and meaningful learning. The value of this experience has as much to do with the setting and context in which it is delivered as it does with what is being said.

\section{B. The Project's Oral History Seminar and How it Works}

Before the start of each class, I compile a list of attorneys who are likely to have interesting and informative life stories. Then, fifteen students select fifteen attorneys and judges to interview from the list. There is no science in compiling this list; I frequently approve student requests to interview attorneys or judges whom they know or in whom they have a particular interest and who are not on the list or previously known to me. Students will invest considerable effort in seminar work, and it is important that they begin the project with enthusiasm for the undertaking. I urge them to look for an individual to interview whose life story is likely to speak to them. For a student who wants to enter corporate practice, this may be a managing partner of a large corporate firm. For someone who plans to practice in a small town, this might be an older, small town practitioner who has devoted his life to the community. Women and

14. Id.

15. For example, James E. Ferguson is one of North Carolina's leading trial attorneys and has handled numerous high-profile civil rights cases, including the "Wilmington 10" case (involving a clash between Wilmington, N.C., police and African-American protesters, including the Reverend Benjamin F. Chavis, in 1971) and the case of the "Charlotte 3" (involving the trial of three African-American activists on charges of burning a stable and horses in Charlotte, N.C., in 1968). 
minority students frequently choose women and minority attorneys because they believe those stories will particularly inform their own perspective. While some of the people interviewed are older and more famous members of the bar, others are not. A relatively young woman who, as a working mother, put herself through law school, practiced with a small firm, hung out her own shingle, and then ran for the legislature might provide a much more instructive and interesting life story to a young law student trying to decide what sort of practice and life she wants than someone who took a more traditional route.

Occasionally, students interview people they do not expect to admire or whose lives they do not want to emulate. If the life is interesting, this too can yield a very instructive life story and can, perhaps, stimulate even more reflection on the part of the student. ${ }^{16}$ Generally, the names I recommend are of lawyers who are recognized as "successful" in terms of professional accomplishment and who have a positive attitude about the role of lawyers in society. However, it can be very worthwhile for a student to interview an attorney (or ex-attorney) who has been disciplined by the Bar or otherwise involved in an ethical controversy.

The first few classes in the seminar are devoted to training students in the skills and etiquette of interviewing and to encouraging them to open themselves to a new and emotionally deeper type of learning experience. Each student is required to keep a journal of her experience in the course. The journal is intended to be a periodic reflection on the life of the person being interviewed and the personal thoughts of the student about her own life and the profession she has chosen. Interviews vary in length, but each student is expected to conduct a minimum of two sessions of approximately two-and-one-half hours per session. Each student makes an oral presentation to the class and writes a seminar-length term paper. The oral presentation and the paper serve to inform the class about the life of the person interviewed and the lessons that person's life story teaches us about lawyers as people and as professionals. In their papers, class presentations, and in textual reflection, students are encouraged to relate the lessons they perceive to the meaning those lessons have for them personally and as future professionals.

This format involves risk for the students because they are asked to bring to the course aspects of themselves that are traditionally excluded from law school classes. Initially, students will vary widely in their willingness to do this, but as the semester progresses and as more students make their oral presentations, a new dynamic begins. The class members begin to talk more freely and

16. In some of these interviews, students change their minds about the lifestyle and type of practice they think they want. In other interviews, their doubts are confirmed. A young woman student who interviewed one of the earliest and most successful female corporate lawyers in North Carolina concluded in her class presentation and final paper that she did not wish to make the personal sacrifice necessary to follow the same career course and questioned the interviewee's assertion that women attorneys must accept the existing realities of corporate practice if they wish to succeed as corporate attorneys. 
openly about professionalism and the lawyer's role in terms of their own values and their own experiences. Students confront issues more directly and, in so doing, expose the side of themselves that is first a person with values and moral understanding and second an aspiring professional.

Under this format, the role of the teacher differs from that in a more traditional law school seminar. In the oral history seminar, the class material is "context oriented," in the sense that the lessons of the course arise from a context generated by the course itself. The course work, then, serves both to produce the context and to help students understand what the work says and teaches. This context, which can be described as the life stories of the lawyers and judges supplemented with the commentary and response of the class, becomes, in effect, the text for the course.

The value issues that arise from this text, while predictable to some degree, arise without prior notice during the interviews themselves and as the stories are told to and discussed by the class. In the interview itself, where only the student and interviewee are present, the learning depends on the student's preparation for the interview and her consciousness of ethical issues. I have tried to assist this process by meeting at least once individually with each student before the interview begins to help identify fruitful areas of inquiry and to speculate on what value issues might arise. I have also met frequently with students while interviews are in progress, typically between the first and second interview.

When value issues arise in class as a student presents a life story, I try to assist the learning process by helping students identify the issues and by asking questions to encourage open reflection upon those issues in the context the class has developed. Because that context is immediately present in the form of the life story being presented and the student's interpretation of that story, the context is deep, rich, and meaningful. Students respond with thoughtful and sometimes intense class discussions. Part of my job, and an increasingly important aspect of it as the semester progresses, is to know when to stay out of the way and let learning occur.

Beyond this, however, there is an obvious structural problem: There is no prior plan of what the text will be, or of what issues will arise, and when. This can lead to uneasiness in both students and teacher-a concern that serious content will not be forthcoming and that, if it is, it will be disconnected and impractical. It is important, therefore, for the teacher to begin to build a loose structure as the class progresses by helping students see connections between similar issues in different stories. In this way, value issues take on more credibility as issues of professionalism rather than merely the personal problems of one lawyer. This process can also be assisted by reference to the teacher's own experience in the profession and to pertinent case law and professional rules.

From their work in the oral history seminar, students gain a clearer view of the lives and work of lawyers and a deeper understanding of professionalism. 
Students also gain a deeper understanding of the conflicts inherent in the lives of lawyers, in the profession, in the adversarial system, and between the profession and society. Most students also begin (or renew) the process of reflecting upon their own moral limits--what they are, where they come from, what value they have, and how they will be challenged by the demands of a lawyer's life. For some students this can be a fairly wrenching experience; some leave the seminar with more doubts about the profession and their place in it than when they entered.

The oral histories also expose students to criticism of the profession from some of its most prominent members. It is in the context of this criticism that the more traditional issues of legal ethics usually arise. Some older interviewees deplore the commercialization of the profession and what they perceive as a general decline in professional image and standards, particularly in regard to ideals of service to clients and to the community. They identify lawyer advertising as the primary cause for the decline, followed closely by the advent of the billable hour. ${ }^{17}$ Interviewees often denounce what they see as a growing "win-at-all-costs" mentality and an increasing use of over-zealous tactics. At the same time, students hear in the life stories the conflicts inherent in the lawyer's role between duty to the client's interest and one's own moral hesitation: In describing some of their own tactics, lawyers often seem disturbed or unclear about how the decision to use those tactics comports with their own morals or their attitudes about professional values. Interviewers are also frequently ambivalent about where to draw the line between over-zealousness and good lawyering. Interviewees express shame and outrage, as Judge Snepp did, ${ }^{18}$ over incidents of embezzlement of client funds and other incidents of lawyer chicanery and dishonesty. They worry about the loss of civility among attorneys and about racism and sexism in the Bar, the existence of which is amply illustrated by graphic examples from women and minority attorneys. ${ }^{19}$

17. This is fairly uniform among older lawyers, with some of the strongest critics of the billable hour coming from attorneys working in large corporate firms.

18. See Interview with Judge Frank W. Snepp, supra text accompanying note 1.

19. For example, Judge Gregory Weeks, now a state superior court judge, described his early experiences as an African-American lawyer in Fayetteville, N.C., in the late 1970s as a version of what he termed the "organ grinder syndrome":

[W] hen I was young we used to have folks standing on the street corner with their accordions and monkeys . . . and folks would stop because that monkey acted almost human .... I think to some extent that happens to black lawyers. When we walk into the courtroom-after they decide you're not the defendant, you're the lawyer-their expectation level is low. And because their expectation level is low, anything that you do that is unexpected is given greater credence, more significance .... I think that worked to my advantage. It could also work to my disadvantage. I went through a state where I lost about four or five cases, I don't think I should have lost, at least not that quickly. Not in that way. It was because I was beating up on my white opponents and reveling in it. That was a no-no. You have to remember who you are.

Interview with Judge Gregory A. Weeks, Cumberland County Superior Court, in Durham, N.C. (Apr. 12, 1994) (by UNC law student Yvone E. Bullock). Katie Holliday, Director of the Children's Law Center in Charlotte, N.C., described her first day of work as a young associate at a law firm in Charlotte: 
But perhaps the most important legacy of the oral history seminar is that it exposes students to members of the profession who openly discuss the morality of their life's work. This is an important image even where students do not themselves agree with the morality of the work in question. One of the first student presentations in the UNC Project was on the life story of former North Carolina Supreme Court Justice I. Beverly Lake, Sr., who, as an attorney, wrote the amicus brief for the State of North Carolina in Brown v. Board of Education of Topeka. ${ }^{20}$ In his interview at the age of eighty-six, Justice Lake continued to expound the "separate but equal" argument against school integration as both constitutionally sound and as a personal preference. ${ }^{21}$ The entire class felt Justice Lake's position was wrong, either as a legal or moral proposition, and some expressed open repugnance. But this life story forced students to confront the moral choices attorneys and other professionals must make and live with as individuals. The life story presented the image of a lawyer who, late in his life, felt the necessity to defend the morality of his life's work.

This image is the strongest when a highly respected lawyer or judge states emphatically his belief in the moral value of lawyer's work in general and the moral value of the profession. Some affirm these feelings in eloquent and ringing language:

"I feel a high sense of calling when asked to defend an accused. It is my belief that Christ speaks to us when we stand with one who is alone and afraid. I know that we are doing God's will when we demand due process under law. I know that without the efforts of criminal lawyers, mistaken convictions ... would be commonplace. I know that without the efforts of criminal lawyers, Governor Martin would not have spared the life of Anson Maynard ${ }^{22}$ recently. I know that without the efforts of criminal lawyers, we would have a most efficient criminal justice system which ignores the Magna Carta, which ignores common law, which ignores the Bill of Rights, and which bans Bibles, burns witches and hangs heretics." So that's my position, and that's my belief. $^{23}$

One of the senior partners ... took me in to his office and said, "I just want you to know that I, basically, didn't want [this law firm] to hire [women]. I don't approve of women practicing law. And my wife doesn't want there to be a female attorney in this office." . . He was much smoother about it than this, but this was bottom line. "And if you attend firm meetings, I won't attend firm meetings. You and I will never work on a case together." And then the kicker was, he said, "And if I should, for instance, ever run into you at the opera or the symphony, don't even attempt to speak because we're not going to do this introduction thing." And I have vivid memories of being at home that night in the bathtub crying, saying, "Do I go back tomorrow?"

Interview with Katherine S. Holliday, Attorney, in Charlotte, N.C. (Feb. 18, 1994) (by UNC law student Charlotte Cooper Gaskins).

20. 349 U.S. 294 (1954).

21. Interview with I. Beverly Lake, Sr., in Wake Forest, N.C. (Feb. 18, 1992) (by UNC law student Edward L. Harrelson).

22. Anson Maynard was sentenced by the State of North Carolina to die on January 17, 1992, by lethal injection for the murder of a State's witness in an armed robbery. On January 12, 1992, Governor James Martin commuted his sentence to life in prison without parole.

23. Interview with Robert L. McMillan, Jr.. Attorney, in Raleigh, N.C. (Feb. 2, 1992) (by UNC law student Grady Balentine, Jr.) (reading from a speech he delivered in his church). 
And they often speak in very positive terms about the profession itself:

The lawyers I work with in my firm and in this region of the world, and even in other cities I work [in], . . are honest people. They are very honest. They are the best; they're the best group of people. They're the most fun. They're the most intelligent. And I think it's still true, that probably the best young women and men that we produce aspire to be lawyers. And maybe all [law students] need . . ., if there are any now who feel a bit negative, maybe they just need to hear those of us who are out here practicing say the things I'm saying, that it is a great profession. ${ }^{24}$

Law students rarely hear moral affirmations of the profession or the honesty of lawyers in law school, and they tend to discount them when they do. They hear it even more rarely from persons outside the profession. But they hear it when they talk to lawyers who live those affirmations and who truly believe in the decency of their fellow members of the bar. While this does not eradicate the deep ethical problems among lawyers and in lawyers' work, it does tell students that they can live a morally worthy life in the law, that they have some control over the moral choices in their future, and that there are people in the profession who are living by principle and thriving.

\section{The Intergenerational Aspect and Involvement of the Bar}

The UNC Project seeks to draw on and revitalize a tradition within the Bar: The elders of the profession teach the mysteries and professional values of lawyering to its initiates. ${ }^{25}$ The intention here is twofold. First, as discussed above, experience with the oral history interview indicates that initiates learn the values of the profession best from other professionals who, by virtue of their longevity, status, and life experiences, can attest to the need for personal and professional standards and to the ability of individual attorneys to maintain those standards in the "real world." Second, placing responsibility for teaching professional values on lawyers and judges involves the Bar in its proper and long-neglected role as the primary sustainer and teacher of those values. Acceptance of this responsibility, as one attorney who has participated in an oral history interview has confided, allows you to "examine your own life." 26 It engages lawyers in a reflective process that is necessary, both to the

24. Interview with Wade Marvin Smith, Attorney, in Raleigh, N.C. (Mar. 9, 1992) (by UNC law student Kimberly Thigpen).

25. The apprenticeship system was the primary means of gaining legal training for American lawyers during the Colonial Period and well into the 19th Century. See Paul D. Carrington, The Theme of Early American Law Teaching: the Political Ethics of Francis Lieber, 42 J. LEGAL EDUC. 339, 339 (1992); Craig Evan Klafter, The Influence of Vocational Law Schools on the Origins of American Legal Thought, 1779-1829, 37 AM. J. LEGAL HIST. 307, 310-14 (1993); Charles R. McManis, The History of First Century of American Legal Education: A Revision Perspective, 59 WASH. U. L.Q. 597, 601-09 (1981); Ralph Michael Stein, The Path of Legal Education from Edward I to Langdell: A History of Insular Reaction, 57 CHI.-KENT L. REV. 429, 437-45 (1981); see also AlBERT J. HARNO, LEGAL EDUCATION IN THE UNITEd STATES 18-23 (1953); ROBERT STEVENS, LAW SCHOOL: LEgal EDUCATION IN AMERICA FROM THE 1850S TO THE 1980S 1-19 (1983) (discussing early American legal education generally).

26. B.B. Olive, Address at the First Annual Meeting of the Advisory Committee for the UNC Intergenerational Legal Ethics Project (Dec. 3, 1994). 
profession and its members, to recollect and nurture moral purpose. This process, as well as the learning and values it engenders, is an essential legacy within any group that aspires to be thought of as a profession.

\section{Developing a Mentoring Program}

A second phase of the UNC Project is development of a mentoring model that recreates the pedagogical success of the oral history seminar in a format involving more lawyers and students. Ultimately the ambition here is quite grand: Every law student in North Carolina and every person who enters the North Carolina Bar-and, finally, every bar in the country-should be engaged with at least one experienced and respected member of the profession in an ongoing relationship in which both mentor and initiate examine the purposes, goals, and values of lawyers' work and the meaning of professionalism. The UNC Project has designed the model to provide methods and standards for broader action by law schools and state bars.

In its initial conception, the UNC mentoring project will be a one-hour component of a three-hour ethics course with the mentoring relationship to begin in the early fall of the school year and the two-hour classroom component to be taught in the spring semester. The mentoring component will match thirty-six lawyers and judges with thirty-six law students in mentoring relationships that will serve as one component of a three-hour course in professional ethics. ${ }^{27}$ Mentors and students will meet together at a two-day retreat early in the fall where they will pair off and participate in group and individual activities designed to begin the reflective process. A small group of professional elders will initiate the process by discussing their own concerns about the current state of professional values and by relating their experiences as mentors or mentorees. Lawyers and student partners will participate in group sessions where issues of professionalism and the meaning of a professional life are explored. Thereafter, during the school year, students and practitioners will meet in pairs periodically for continued consultation and mutual reffection. On at least one day during the school year, students will visit the practitioners and spend the day "shadowing" them in their work. Students will keep a journal of their thoughts and experiences; mentors will be encouraged to do so as well. Finally, students will write papers reflecting upon what they have learned from their relationships with judges and lawyers and the effects of those relationships on their personal views of the profession and professional values.

The central focus of this mentoring model is individual contact between student and mentor in settings and under conditions that maximize the opportunity for reflective learning by both parties. The classroom component of this model will attempt to draw upon students' experiences in the ongoing

27. The two-hour classroom component of this course, discussed in the next section, is being taught for the first time by the author in the 1996 spring semester at UNC Law School. 
mentoring process. Toward that end, the class will employ teaching methods designed to create space and opportunity for individual reflection and for group sharing of mentoring experiences.

E. The Classroom Component of the Legal Ethics Course: Elements of a Successful Learning Environment

In rethinking formats for teaching ethics in a law school classroom, the challenge is to create contexts, similar to those that occur naturally in the oral history interview, in which value discussions become meaningful on both a professional and personal level. In order to do this, the UNC Project is experimenting with different teaching techniques as well as innovative teaching materials. Some of these tools are drawn from our experience in the oral history project and from the trial and error efforts of previous classes. Others are drawn from the increasingly rich field of educational theory ${ }^{28}$ and the expanding literature on the use of new techniques in law school teaching. ${ }^{29} \mathrm{~A}$ detailed description of these techniques and materials exceeds the purpose of this article, but even at this early stage of the project, three axioms are apparent.

1. Student Involvement In the Class and Responsibility for the Learning Process are Essential to a Meaningful Learning Experience. If students are to deal with ethical and moral issues on a personal level, they need to be given-and to accept-significant responsibility for their own education and development. One of the reasons frequently given for not engaging students on this level in law school is that law professors (and law schools) have no authority to teach morality and no business trying to tell students what is right and wrong. Whether this is true or not, from my experience, students tend to either reject or ignore teaching efforts that they perceive as moral preaching. But that is not to say that law schools cannot or should not attempt to affect students' moral development. Law schools can openly recognize that development of one's own moral character is an integral part of practicing as a

28. See SCHON, supra note 4. Other authorities, many of whom have been influenced by the work of Schön, are discussed in an excellent article, Brook Baker, Beyond MacCrate: The Role of Context, Experience, Theory, and Reflection in Ecological Learning, 36 ARIZ. L. REV. 287 (1994); see also Gary L. Laser, Educating for Professional Competence in the Twenty-First Century: Educational Reform at Chicago-Kent College of Law, 68 CHI.-KENT L. REV. 243 (1992) (also discussing Schön's work as applied in a law school curriculum).

29. See, e.g., James R. Elkins, Writing Our Lives: Making Introspective Writing a Part of Legal Education, 29 WillameTte L. REV. 45 (1993); Cathaleen A. Roach, A River Runs Through It: Tapping Into the Informational Stream to Move Students From Isolation to Autonomy, 36 ARIZ. L. REV. 667 (1994); Auturo L. Torres \& Karen E. Harwood, Moving Beyond Langdell: An Annotated Bibliography of Current Methods for Law Teaching, Special Edition, GoNz. L. REV. 1 (1994); Mark Weisberg \& Jacalyn Duffin, Evoking the Moral Imagination: Using Stories to Teach Ethics and Professionalism to Nursing, Medical, and Law Students, CHANGE, Jan.-Feb. 1995, at 21; James Boyd White, Doctrine in a Vacuum: Reflections on What a Law School Ought (and Ought Not) to Be, $18 \mathrm{U}$. MICH. J. L. REF. 251 (1985). 
professional, and they can exercise their authority to provide the environment and encouragement necessary for individual development to occur.

How is this accomplished in a system designed for classes in which an allknowing professor directs large numbers of confused, and, often increasingly disinterested, students through a labyrinthine, Socratic dialogue to the kernel of truth hidden deep in the professor's mind? The answer-or at least one answer-lies in a reconception of roles in the classroom. The truth on moral issues does not lie in the mind of the professor; it lies within the heart and soul of the student. Further, the professor is not all-knowing because the journey inward to one's heart and soul is a journey each must take alone. In addition, it is characteristically a journey without a definite goal in mind. Frequently there is no "kernel of truth," but rather a truthful coming to terms with the composition of one's own character. The journey is, thus, by nature openended. Professors cannot direct these journeys for students, and they cannot herd students along some preconceived route. About the best a professor can do in this context is to give permission and encouragement for the undertaking to occur. But this is not an easy task. It involves surrender of control and power. It involves trusting students in the process. It involves taking the risk to be seen as engaged in one's own journey of the heart.

\section{In Order for Reflective Learning to Occur, There Must Be a Safe Place} for Introspection and Risk-Taking. This is difficult to accomplish in an educational setting where competition and individual achievement are openly encouraged. Admission of doubt and uncertainty, self-critique, admission of error and risk of exposure of imperfection-all valid exercises in the reflective process-are anathemas to many law students. To encourage exercise of these processes in the current law school context requires creation of an enclave, a safe zone, where expression of such thoughts and feelings is possible. A key step in this process involves giving permission for that sort of expression. Both what the teacher says about the course and a course structure that encourages creative thinking and expression can reassure students that, unlike most other law school courses, personal reflection and expression are part of the learning process.

Another key step is for the teacher to lead by example. This involves risk, but it is unreasonable to ask law students to risk self-exposure if the professor is unwilling to do so. One way of doing this is for the teacher to begin with a personal anecdote that illustrates learning through reflection. I have used a story about my own early days as a practicing attorney. After law school, my devotion to liberal ideals led me to employment at a civil rights firm that specialized in First Amendment cases. One of my first assignments was to assist our client, the local chapter of the Ku Klux Klan, to obtain a parade permit. Immediately, I was in a very complicated ethical and moral quandary. Not only were my own political ideals in conflict, but some of those ideals conflicted with one of my professional ideals as well: to do my best for my client. This was an agonizing experience for me, and to this day I am unsettled about it and 
continue to reflect upon it and learn about myself and my relation to the profession. It is this image of the lawyer reflecting upon the morality of his acts that students need to see to encourage them to begin that process themselves. ${ }^{30}$

3. In Order for Reflective Learning To Occur, It Is Necessary to Use Learning Materials and Methods That Draw Students Into the Process While Expanding the Learning Context Beyond the Boundaries of the Law School. The classroom methods utilized by the UNC Project are basically efforts to create an atmosphere where honest and open reflection can occur, both individually and in groups. The use of journals, in-class and out-of-class essays on introspective topics, final papers with an emphasis on personal reflection, small group discussions of issues designed to cause personal reflection, class presentations by individuals and groups designed to elicit personal reflection (including talks by individual or panels of practicing attorneys), class-wide discussion where permission to speak from a personal conviction is openly encouraged, and reading aloud in class ${ }^{31}$ by students and professor are all methods that have achieved some measure of success.

Of these methods, perhaps journals and reflective papers provide the best opportunity for students to look inside themselves for moral questions and answers. Journals promote an ongoing reflective process and allow the teacher who reads them to use written observations and comments to converse intimately with the student on the issues confronted. In my professional responsibility class, I have required brief in-class essays on "The Moral Reasons I Want to be a Lawyer." I have assigned short outside-of-class papers asking students to, for example, describe one event or person in their childhoods that significantly affected development of their moral character and explain why, or describe the effect law school has had upon their moral outlook and moral image of themselves.

These exercises have yielded some profound results-not only in terms of what students say and the stories they tell-but in how freely they open up to the process. For example, a student with an abusive, alcoholic father might begin to realize that her main motive for going to law school was to be able to stand up to her father and that this motive is not likely to sustain her through the rigors of law school or practice. A student who has had a strong, negative

30. A safe zone for reflective thinking and discussion of ethical and moral issues should not become a zone for emotional self-indulgence and indecision. An important aspect of encouraging ethical reflection in law students is to remind them that the role of attomey requires them to make timely decisions and accept the consequences of those decisions. At some point for lawyers, moral reflection must give way to action (though reflection will, one hopes, never cease). I am especially watchful for students who seem to "bog down" in the reflective process and use it as an excuse either for rejecting the lawyer's role altogether or for perpetual indecision.

31. Having students read aloud in class from a particularly meaningful text involves students in the work of the class in a remarkable way. It gives them responsibility for presentation of the material. It causes them to listen to the voices of their classmates-not just what is being said, but the voices. It calls attention in a poignant way to the spoken as well as the written word. And when the text is itself evocative, reading it clears the way for the students to respond to it in a more personal way. 
reaction to law school might begin to see how law school has helped him learn to think more clearly, see the complexity in issues, and be able to credit opinions with which he disagrees. Many students begin, upon reflection, to see that they cannot depend on law school or the profession to provide them a foolproof formula for ethical behavior. They must take that responsibility themselves.

Much has been said recently on the use of narrative in law school teaching. ${ }^{32}$ Narratives are particularly helpful in teaching ethics because, like the oral history interview (which is actually one form of narrative), they provide broader contexts in which to view and discuss value questions. These contexts relate lawyers' work to larger issues of morals, personal standards, and life purposes. $^{33}$ The narratives I have used are drawn from works of fiction, ${ }^{34}$ mythology, ${ }^{35}$ law school casebooks, ${ }^{36}$ hypothetical problems, ${ }^{37}$ oral histories, ${ }^{38}$

32. See, e.g., John Batt, Law, Science, and Narrative: Reflectionis on Brain Science, Electronic Media, Story, and Law Learning, 40 J. LEGAL EDUC. 19 (1990); Beryl Blaustone, Teaching Evidence: Storytelling in the Classroom, 41 AM. U. L. REV. 453 (1992); James R. Elkins, The Quest for Meaning: Narrative Accounts of Legal Education, 38 J. LEGAL EDUC. 577 (1988); Elizabeth Villiers Gemmette, Law and Literature: Joining the Class Action, 29 VALP. U. L. REV. 665 (1995); Pedagogy of Narrative: A Symposium, 40 J. LEGAL EdUC. 1 (1990); Robin West, Economic Man and Literary Woman: One Contrast, 39 MERCER L. REV. 867 (1988).

33. James R. Elkins has written, "[A] story is an offer of other worlds of relation and possibilities, other contexts for human action, sentiment, and feeling." James R. Elkins, The Stories We Tell Ourselves in Law, 40 J. LEGAL EDUC. 47, 54 (1990). James Boyd White has explained the experience of reading literary narratives this way:

Reading of this kind thus works by a kind of constant dialogue between the original text and what we can say about it, which is also a dialogue between the other and the self. As we read, the strange becomes familiar, the familiar strange; in the process our own preexisting commitments, our ways of thinking about the world, are exposed to thought and criticism, and we become, for the moment at least, different from what we were.

James Boyd White, What Can a Lawyer Learn from Literature?, 102 HARV. L. REV. 2014, 2019 (1989) (reviewing RICHARD A. POSNER, LAW AND LITERATURE: A MISUNDERSTOOD RELATION (1988)).

34. Two excellent, fictional examples of moral choice in contexts where legality, societal morality, and personal conscience are in conflict are Captain Vere's speech in Herman Melville's "Billy Budd, Sailor" and Huckleberry Finn's internal monologue over whether to turn in his friend Jim as a runaway slave, in Mark Twain's "Huckleberry Finn."

35. The Parsifal myth of the search for the Holy Grail provides a useful vehicle for engaging students on issues of moral consciousness and life purpose in lawyering. The various encounters of the knight errant in his quest for the Grail provide an instructive metaphor for the various stages of a lawyer's professional and personal development. I have used this myth in my professional responsibility class by writing a script for it in which the statements of lawyers-drawn from writings by lawyers and others and from oral histories of lawyers-are used to illustrate the stages and pitfalls of the quest. Students take turns reading the various parts aloud in class as we talk our way through the myth and the ethical and moral issues raised by the script. For example, when Parsifal meets the Red Knight (which in Jungian terms is the super-masculine archetype which Parsifal must conquer in order to begin to bring the masculine and feminine parts of his life in balance), the following statement from Gerry Spence, the famous trial attorney from Wyoming, is used to illustrate the aggressive, go-for-the-jugular attitude prevalent among some members of the bar and to discuss its implications:

My father was a hunter. He loved it. I've spent much of my life revolting against my parents, but now I know I'm imitating them, time and time again. Like Dad's hunting-I'm now a hunter, a combatant in the courtroom. It's just like the forest: I walk through quietly but resolutely, ready to make a purposeful kill. You must have great love to kill, to combat, to advocate. 
and the students' own stories about their lives. The key in regard to method, however, is not so much what is done, but the atmosphere in which it is undertaken. As noted above, initial responsibility for that resides essentially with one person-the teacher.

The experimental efforts of the UNC Project in regard to classroom materials have yielded a basic lesson: In teaching professional ethics, the notion of what constitutes an appropriate text should be expansive and creative in terms of form and content, while remaining meaningfully connected to the real work of the legal profession and the hard issues of personal and professional choice that legal work involves.

\section{CONCLUSION}

The UNC Project is an effort to visualize and construct more effective ways to engender, nurture, and convey professional values to law students and members of the profession. The success of this effort lies in reconnecting issues of professional values to questions of personal and societal morality. This is achieved by encouraging students to view lawyers not only as professionals, but as individuals and members of their communities.

Law schools can and should take the initiative to begin that process, as the UNC Project tries to do. However, the most successful models will ultimately involve the Bar in the essential process of sustaining and revitalizing the ethical standards and personal character of its members. While the reasons for the

Law has had me at war for thirty-five years. Every case I've had left me shell-shocked, fatigued, full of fight. One could say I've played all my life, because I like what I do so, but no, I've been to innumerable fronts of war. It hasn't taken genius to win. It takes energy. Energy.

I rise every morning at five and average a fourteen-hour day. I'm consumed by all this, so time counts. By the way, you didn't ask me when I'll retire. Don't bother. I'll die in court. Richard W. MOLL, THE LURE OF THE LAW 80-81 (1990). Two sources that are helpful explications of the Parsifal myth for use in class are ROBERT A. JOHNSON, HE: UNDERSTANDING MASCULINE PSyChOlOGY (1989) and EMMA JUNG \& MARIE-LOUISE VON FRANZ, The GRAIL LEgEND (Andrea Dykes trans., 2d ed. 1986).

36. Cases are narratives. But we frequently forget this aspect in our single-minded use of them to teach students to think like lawyers. Sometimes I use cases in the standard format to illustrate application of an ethical principle or rule of law. But I also use them as narratives. Rather than narrowing focus toward a specific issue or rule, the narrative approach uses the context of the case to broaden discussion and look for wider moral and philosophical implications.

37. Hypothetical problems, like cases, can be used to either focus inquiry or expand it. I use them in both ways. In conjunction with the ABA Model Rules of Professional Conduct, they provide a basis for class-wide or small group discussion on both issues of rule compliance and transcendent moral questions. One approach that has proven effective under this format is to divide the class into small groups of three to five students and assign two groups to each hypothetical problem. One group is assigned to analyze the problem in terms of the applicable law and professional rules and standards and present that analysis to the class. The second group is assigned to respond to the problem in terms of personal conscience and societal morality. The tension between these two approaches can lead to a lively and informative class-wide discussion.

38. See, e.g., the use described supra note 35 . 
current ethical crisis in the legal profession are, no doubt, diverse and spread throughout the profession and society as a whole, it is ultimately the members of the profession who must take the steps to deal with it. 